\title{
ICA Joint Seminar 1996 in Gifu/Japan
}

Anläßlich des japanischen „Map Summit Gifu 96“ fand vom 8. bis 11 . November 1996 ein ICA Joint Seminar in Gifu/Japan statt. An diesem Seminar war die ICA (International Cartographic Association, Internationale Kartographische Vereinigung) mit folgenden Kommissionen beteiligt: Standing Commission on Education and Training, Commission on Theoretical Fields and Definitions in Cartography, Commission on Map Use, Working Group on Cartography for Children. Thema des ICA-Seminars war: "Cognitive Maps, Children and Education in Cartography“.

Der Veranstaltungsort war Gifu in Japan, eine aufstrebende Industriestadt mit über 400000 Einwohnern, die sich auf Honshu weiträumig zwischen den durch aufwendige Deichbauten hochwasserregulierten Flüssen Kiso, Ibi und Nagara erstreckt. Gifu ist eine Autostunde vom internationalen Flugplatz Nagoya entfernt.

Die Räumlichkeiten für das Seminar befanden sich in der „Prefectural Library“, ein in großzügiger Architektur entstandener Komplex. Die „Prefectural Library“ wurde im Juli 1995 eröffnet unter dem Motto „Offenheit - Partizipation Kreativität“. Sie soll ein Platz der Information und Kommunikation sein, der die Menschen lernend und kreativ zusammen sein läßt. In der „Prefectural Library“ in Gifu befindet sich das „World Distribution Map Center“.

Der Gouverneur der Präfektur Gifu, Taku Kajiwara, sprach die Grußworte zur Eröffnung des „Map Summit Gifu '96“ an die ca. 200 japanischen Teilnehmer. Die Grußworte an die Teilnehmer des ICA Joint Seminars sprach Tositomo Kanakubo, Vize-Präsident der ICA. Den Eröffnungsvortrag hielt Michael Wood, Präsident der ICA, zu dem Thema,Cartography into the New Millenium:. Die weiteren Vortragenden und Themen waren:

Evangelos Livieratos, Aristotle University of Thessaloniki, Greece: On Some Fundamental
Cognitive Issues in Cartographic Education. Yoshiki Wakabayashi, Tokyo Metropolitan University, Japan: The Role of Analogical Thinking in Cognitive Map Studies. - Takashi Morita, Hosei University, Japan: The Role of Non Explicit Symbolization in Map Expression. - Ni Shaoxiang und Lu Shufeng, Nanjing Normal University, China: Pedagogic Maps for Children in China. - Jacqueline M. Anderson, Concordia University, Canada: „I Love Maps ... but is that a Road Map or a Weather Map?" The Knowledge of Maps and Attitudes towards Mapping in Quebec Schools (Kindergarten, Grades 1-11). - Patrik Wiegand, University of Leeds, U.K.: Children's Representation of the Earth's Land Masses on Plane and Spherical Surfaces. - Chyssoula Boutoura, Aristotle University of Tessaloniki, Greece: Institutional Schemes for the Barbara Petchenik Children Map Contest in Greece. - Ferjan Ormeling, Utrecht University, The Netherlands: Teaching Cartographic Concepts to Children. Hans-Uli Feldmann, Swiss Federal Office of Topography, Switzerland: Fun and Games in Learning How to Read Maps. - Wolfgang Meissner, Dortmund Municipal Survey and Cadastral Office, Germany: Cognitive Maps, Children and Education in Cartography - Three Examples. - Milan Konecny und Josef Svancara, Masaryk University, Czech Republik: (A)perception of Maps by Czech School Children. - James R. Carter, Illinois State University, U.S.A: Maps for Children on the World Wide Web.

Die Ergebnisse dieses Seminars werden in einem gemeinsamen Report in englischer und japanischer Sprache veröffentlicht. Die englische Ausgabe wird auf dem 18. Internationalen Kartographischen Kongreß im Juni 1997 in Stockholm/Schweden vorliegen. Die japanische Ausgabe wird zur Unterrichtung den japanischen Schulen und Hochschulen bereitgestellt.

Wolfgang Meißner, Dortmund

\section{Vorankündigung Niederdollendorf-Kurs}

Der Arbeitskreis „Praktische Kartographie“ der Deutschen Gesellschaft für Kartographie setzt in diesem Jahr die lange Tradition der Niederdollendorf-Arbeitskurse fort. An neuer Tagungsstätte, in Königlutter am Elm, wird unter dem Leithema "Anwenderforum digitale Kartographie" vom 29. 9. bis 2. 10. 1997 der 21. Arbeitskurs stattfinden. Beachten Sie die Programm-Vorschau in KN 2/97, S. 76 f. Weitere Informationen: VermDir. B. Horst, Tel. 0511/3673-250, Fax $0511 / 3673-547$. 